\title{
THE INCIDENCE OF PERTHES' DISEASE IN THREE POPULATION GROUPS IN THE EASTERN CAPE REGION OF SOUTH AFRICA
}

\author{
N. A. PURRY
}

From the Department of Orthopaedics, Livingstone Hospital, Port Elizabeth, South Africa

\begin{abstract}
Perthes' disease is thought to be rare in black children but no figures of incidence have previously been available. A search was therefore made for cases of the disease occurring in the Eastern Cape during the fiveyear period 1975 to 1979 . Of 55 cases found, 38 were in white children, 11 in children of mixed ancestry ("coloured" children) and six in black children. The annual incidence in white children aged 14 years and under was 10.8 per 100000 , in coloured children 1.7 per 100000 , and in black children 0.45 per 100000 . In all races the incidence in the metropolitan area of Port Elizabeth was roughly twice that in the rural part of the region. The reason for the low incidence in coloured and black children is not known but various factors are suggested.
\end{abstract}

Perthes' disease has attracted much attention in recent years because of its uncertain aetiology, the prolonged treatment required during its active phase, and the permanent changes that may remain to cause trouble in later life. For these reasons most investigations have concerned aetiology and treatment. Comparatively few studies have been made of the actual incidence of the disease. It is widely thought to be rare in black children (Trueta 1960; Chung and Ralston 1969; Fisher 1972; Kelsey 1977) although Cockshott and Palmer (1960) deny this. I am not aware of any publication that has recorded the incidence in these children or compared it with that in other population groups. This measurement and comparison is the object of this paper.

\section{PATIENTS AND METHODS}

The Eastern Cape Region on the southern coast of Africa extends about 200 kilometres on either side of the city of Port Elizabeth and about $\mathbf{4 0 0}$ kilometres inland. The total population at the midpoint of this survey was just over one million people, consisting of about 228000 persons of European descent ("Whites"), 572000 persons of indigenous African descent ("Blacks") and 281000 persons of mixed descent ("Coloureds"), as well as a few thousand persons of Asiatic descent. These figures are derived by interpolating between the censuses of 1970 and 1980 (Secretary for Statistics 1970, 1980). Figures are not yet available for population by age groups in 1980 so the 1970 figures for children have been adjusted by the same proportions as the total populations have changed, namely +3.5 per cent for city Whites, -9.4 per cent for rural Whites, +16 per cent for city Coloureds, +0.8 per cent for rural Coloureds, +22.2 per cent for city Blacks and -0.3 per cent for rural Blacks.

The city of Port Elizabeth is a major South African port and, together with the adjacent town of Uitenhage, a manufacturing centre especially of motor cars and footwear. The rest of the Eastern Cape is agricultural, producing mainly wool and fruit. There are 12 specialist orthopaedic surgeons in the region of whom one is resident in Grahamstown and the rest all live in Port Elizabeth. Most children N. A. Purry, FRCS, Senior Specialist in Orthopaedics Livingstone Hospital, P. O. Korsten, Port Elizabeth, 6014, South Africa. (C) 1982 British Editorial Society of Bone and Joint Surgery 0301-620X/82/3063-0286 \$2.00 with chronic orthopaedic conditions are referred to the Walton Orthopaedic Hospital or the Livingstone Hospital, both in Port Elizabeth.

In order to estimate the incidence of Perthes' disease in the Eastern Cape a search was made of the records of the Walton and Livingstone Hospitals for the five-year period January 11975 to December 311979. In addition, a questionnaire was sent to all orthopaedic surgeons practising in the area and to the orthopaedic nursing sisters and appliance workshops.

\section{RESULTS}

Fifty-five cases of Perthes' disease were diagnosed in the Eastern Cape during the five years 1975 to 1979 , of which 38 were in white children, 11 in coloured children and six in black children. The annual incidence in white children aged 14 years and under was 10.8 per 100000 , in coloured children 1.7 per 100000 and in black children 0.45 per

Table I. Incidence of Perthes disease in Eastern Cape 1975 to 1979

\begin{tabular}{|c|c|c|c|c|c|}
\hline $\begin{array}{l}\text { Population } \\
\text { group }\end{array}$ & Area & $\begin{array}{l}\text { Number } \\
\text { of cases }\end{array}$ & $\begin{array}{l}\text { Population } \\
0-14 \text { years }\end{array}$ & $\begin{array}{c}\begin{array}{c}\text { Annual } \\
\text { inci- } \\
\text { dence } \\
\text { per }\end{array} \\
100000\end{array}$ & $\begin{array}{l}\text { Attack } \\
\text { rate }\end{array}$ \\
\hline White & $\begin{array}{l}\text { Urban } \\
\text { Rural } \\
\text { Total }\end{array}$ & $\begin{array}{r}32 \\
6 \\
38\end{array}$ & $\begin{array}{l}50815 \\
19858 \\
70673\end{array}$ & $\begin{array}{r}12.6 \\
6.0 \\
10.8\end{array}$ & $\begin{array}{l}1: 530 \\
1: 1110 \\
1: 620\end{array}$ \\
\hline Coloured & $\begin{array}{l}\text { Urban } \\
\text { Rural } \\
\text { Total }\end{array}$ & $\begin{array}{r}6 \\
5 \\
11\end{array}$ & $\begin{array}{r}55068 \\
72110 \\
127178\end{array}$ & $\begin{array}{l}2.2 \\
1.4 \\
1.73\end{array}$ & $\begin{array}{l}1: 3030 \\
1: 4760 \\
1: 3850\end{array}$ \\
\hline Black & $\begin{array}{l}\text { Urban } \\
\text { Rural } \\
\text { Total }\end{array}$ & $\begin{array}{l}4 \\
2 \\
6\end{array}$ & $\begin{array}{l}112226 \\
143585 \\
255811\end{array}$ & $\begin{array}{l}0.7 \\
0.28 \\
0.45\end{array}$ & $\begin{array}{l}1: 9520 \\
1: 23810 \\
1: 14810\end{array}$ \\
\hline $\begin{array}{l}\text { All groups } \\
\text { combined }\end{array}$ & $\begin{array}{l}\text { Urban } \\
\text { Rural } \\
\text { Total }\end{array}$ & $\begin{array}{l}42 \\
13 \\
55\end{array}$ & $\begin{array}{l}218109 \\
235553 \\
453662\end{array}$ & $\begin{array}{l}3.85 \\
1.10 \\
2.42\end{array}$ & $\begin{array}{l}1: 1730 \\
1: 6060 \\
1: 2750\end{array}$ \\
\hline
\end{tabular}




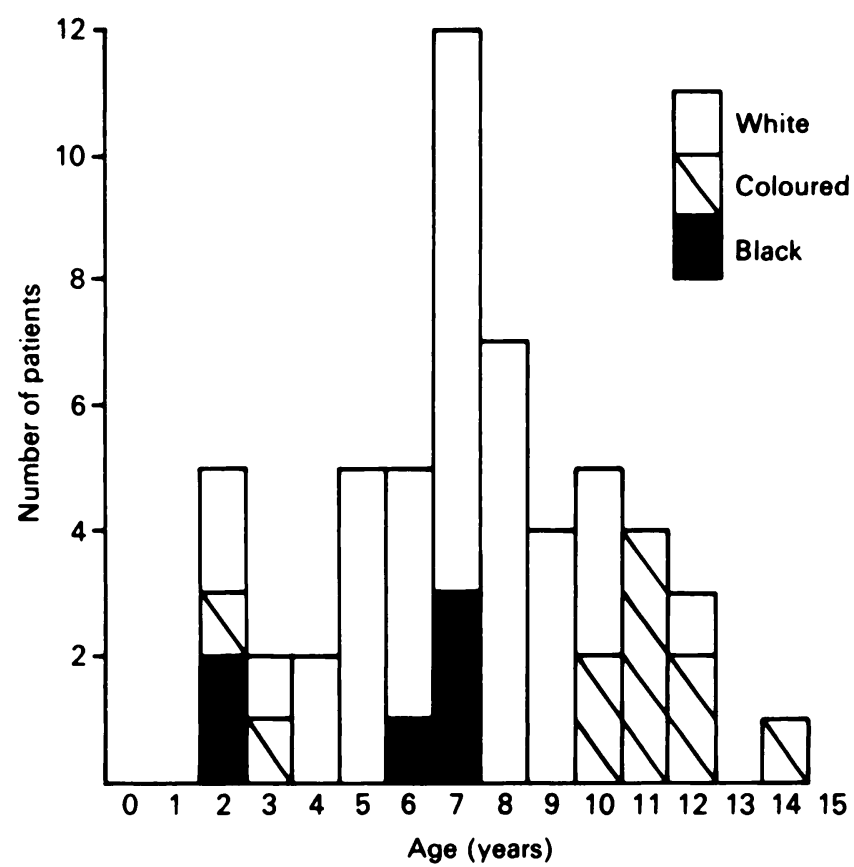

Fig. 1

Number of patients with Perthes disease diagnosed in Eastern Cape 1975 to 1979, analysed by population group and age.

100000 (Table I). If we consider the population of the Eastern Cape as a sample of the population of South Africa, these differences are highly significant when analysed according to standard statistical methods for comparison of proportions. In all races the incidence in the metropolitan area of Port Elizabeth and Uitenhage was roughly twice that in the rural part of the region. These differences are not significant $(P>0.05)$ when the figures for different population groups are analysed

Table II. Number of patients analysed by race and sex

\begin{tabular}{|l|c|c|}
\hline Race & Male & Female \\
\hline White & 31 & 7 \\
Coloured & 9 & 2 \\
Black & 6 & 0 \\
\hline Total & 46 & 9 \\
\hline
\end{tabular}

Table III. Number of cases diagnosed each year

\begin{tabular}{|c|c|c|c|c|}
\hline \multirow{2}{*}{ Date of diagnosis } & \multicolumn{3}{|c|}{ Population group } & \multirow{2}{*}{ Total } \\
\cline { 2 - 4 } & White & Coloured & Black & 11 \\
1975 & 5 & 4 & 2 & 1 \\
1976 & 11 & 4 & 1 & 6 \\
1977 & 5 & 0 & 1 & 6 \\
1978 & 7 & 1 & 1 & 9 \\
1979 & 10 & 2 & 1 & 13 \\
\hline
\end{tabular}

individually, but are highly significant when the figures for the three population groups are combined.

The distribution of cases by age is shown in Figure 1 and by sex in Table II and is similar to that in previously reported series. The number of cases diagnosed each year is shown in Table III. As the cases were collected over five years, the effect of any annual fluctuation in incidence may have been reduced.

\section{DISCUSSION}

Molloy and MacMahon (1966) pointed out that there are at least three ways of measuring the frequency of a condition such as Perthes' disease: the annual incidence measures new cases appearing in a year; the attack rate measures cases appearing in a group of children followed throughout the period of risk; and the prevalence measures cases present in a population at any given time. They provided a direct estimate of annual incidence for Massachussetts in 1964, namely $1: 18000$ (5.7 per 100000 ) white children (both male and female) under 15 years of age. Their estimate of an attack rate of $1: 1200(81.6 \mathrm{per}$ 100000 ) is indirect in that it assumed that the agespecific rates observed in 1964 were the same as those that would have been observed if a single cohort of births had been followed through the entire age period, in other words that the risk of a child of any particular age contracting Perthes' disease does not vary from year to year.

Gray, Lowry and Renwick (1972) found no evidence of changing incidence of Perthes' disease. They measured incidence rates in British Columbia for four periods of four years each (1952-1967). Their overall "minimal annual incidence" was 5.1 per 100000 and their attack rate $1: 1400$.

Harper, Brotherton and Cochlin (1976) measured the number of cases occurring in South Wales between 1939 and 1964 and calculated an attack rate of 1:4750. Barker, Dixon and Taylor (1978) measured the incidence in three regions of England in 1976. Their highest incidence was in the Mersey region and is very similar to my findings in white children in the Eastern Cape; they also found the incidence to be higher in conurbations, which is in keeping with my findings. Their lowest incidence was in Wessex and is similar to those in Massachusetts and British Columbia. These series are compared in Table IV.

No previous investigation has attempted to measure the incidence in black children. Molloy and MacMahon's figures are based on 86 white patients; they found one Negro patient and commented that they would have expected three if the age-specific rates for Negroes had equalled those for Whites. The other incidence figures cited are from surveys that do not refer to the race of the participants. Fisher (1972) found only two black patients out of 203 patients with Perthes' disease occurring in a general hospital population of which four per cent were black children. Trueta (1960) quotes Goff (1954) as 
Table IV. Incidence of Perthes` disease in published series

\begin{tabular}{|l|c|c|}
\hline \multicolumn{1}{|c|}{ Series } & $\begin{array}{c}\text { Annual incidence per } \\
\mathbf{1 0 0 0 0 0}\end{array}$ & Attack rate \\
\hline $\begin{array}{l}\text { Molloy and MacMahon } \\
\text { (Massachusetts) }\end{array}$ & 5.7 & $1: 1200$ \\
$\begin{array}{l}\text { Gray, Lowry and Renwick } \\
\text { (British Columbia) }\end{array}$ & 5.1 & $1: 1400$ \\
$\begin{array}{l}\text { Harper, Brotherton, Cochlin } \\
\text { (South Wales) }\end{array}$ & & $1: 4750$ \\
$\begin{array}{l}\text { Barker, Dixon, Taylor (England) } \\
\text { Mersey }\end{array}$ & 11.1 & \\
$\quad \begin{array}{l}\text { Trent } \\
\text { Wessex }\end{array}$ & 7.6 & \\
$\quad$ Total & 8.5 & \\
Present series (Eastern Cape) & 8.0 & \\
White \\
Coloured & 10.8 & $1: 620$ \\
Black & 1.73 & $1: 3850$ \\
\hline
\end{tabular}

stating that there was not one case of Perthes' disease among 110555 black children admitted to the Charity Hospital in New Orleans between 1941 and 1951 nor at the Hospital for Joint Diseases in New York where 20 per cent of all patients admitted are Negro.

One can only speculate at present as to why this disease is uncommon in Coloureds and even rarer in Blacks. Since it is self-limiting and in its milder grades recovers fully without treatment (Catterall 1971, 1977) it may be suggested that such patients are not presenting for medical care. I do not think this is likely, at least in Port Elizabeth City, since we see many black children with mild and self-limiting conditions. In view of the known association of the disease with low social class and unfavourable environmental conditions (WynneDavies and Gormley 1978) it might be expected to be more common in the less affluent population groups in South Africa, but the reverse is the case.

There is ample histological evidence that part or all of the femoral head is infarcted in Perthes' disease (Somerville 1971) and many authors suggest that more than one ischaemic episode is involved (Kemp 1973; Inoue et al. 1976). Chung (1976) has suggested that there are fewer ascending arteries in the femoral neck in young white children than in black children and this may explain the difference in vulnerability to Perthes' disease. Another possible explanation lies in the faster skeletal maturation of Blacks compared with Whites (Caffey 1968; Fisher 1972). Numerous authors (Fisher 1972; Harrison, Turner and Jacobs 1976; Burwell et al. 1978) have found that skeletal maturation is delayed in children developing the disease so it is suggested that accelerated maturation will protect against the disease. Harper et al. (1976) and Wynne-Davies and Gormley (1978) showed that any genetic component in Perthes' disease is relatively minor. The differing incidence in different races may be due to environmental factors.

It has been the purpose of this paper to provide incidence figures for the disease in three population groups and these figures have demonstrated that its rarity in Blacks is an objective phenomenon and not just a subjective clinical impression.

I wish to thank the Medical Superintendent of the Livingstone Hospital for permission to publish this paper and my colleagues for their encouragement and advice. I am most grateful to Professor N. F. Laubscher of the Department of Mathematical Statistics, University of Port Elizabeth, for performing a statistical analysis of my data.

\section{REFERENCES}

Barker DJP, Dixon E, Taylor JF. Perthes' disease of the hip in three regions of England. J Bone Joint Surg [Br] 1978:60-B:478-80.

Burwell RG, Dangerfield PH, Hall DJ, Vemon CL, Harrison MHM. Perthes' disease: an anthropometric study revealing impaired and disproportionate growth. J Bone Joint Surg [Br] 1978;60-B: 461-77.

Caffey J. The early roentgenographic changes in essential coxa plana: their significance in pathogenesis. AJR 1968:103:620 34.

Catterall A. The natural history of Perthes' disease. J Bone Joint Surg [Br] 1971 ;53-B:37-53.

Catterall A. Perthes' disease. Br Med J 1977:i:1145-9.

Chung SM. The arterial supply of the developing proximal end of the human femur. J Bone Joint Surg [Am] 1976:58-A:961-70.

Chung SM, Ralston EL. Necrosis of the femoral head associated with sickle cell anaemia and its genetic variants. J Bone Joint Surg [Am] 1969: 51-A:33-58.

Cockshott WP, Palmer PE. Perthes'disease (Letters). Lancet 1960;i: 652, 925.

Fisher RL. An epidemiological study of Legg-Perthes disease. J Bone Joint Surg [Am] 1972:54-A:769-78.

Goff CW. Legg-Calvé-Perthes syndrome and related osteochondroses of youth. Springfield, Illinois: Charles C. Thomas, 1954.

Gray IM, Lowry RB, Renwick DHG. Incidence and genetics of Legg-Perthes disease (osteochondritis deformans) in British Columbia: evidence of polygenic determination. J Med Genet 1972;9:197-202.

Harper PS, Brotherton BJ, Cochlin D. Genetic risks in Perthes' disease. Clin Genet 1976;10:178-82.

Harrison MHM, Turner MH, Jacobs P. Skeletal immaturity in Perthes' disease. J Bone Joint Surg [Br] 1976;58-B:37-40.

Inoue A, Freeman MAR, Vernon-Roberts B, Mizuno S. The pathogenesis of Perthes' disease. J Bone Joint Surg [Br] 1976;58-B:453-61.

Kelsey JL. The epidemiology of diseases of the hip: a review of the literature. Int J Epidemiol 1977;6:269-80.

Kemp HBS. Perthes' disease : an experimental and clinical study. Ann R Coll Surg Engl 1973;52:18-35.

Molloy MK, MacMahon B. Incidence of Legg-Perthes disease (osteochondritis deformans). N Engl J Med 1966;275:988-90.

Secretary for Statistics. Population census 1970. Report 02-05-08. Pretoria, South Africa: Government Printer.

Secretary for Statistics. Population census 1980. Preliminary results published 16 Sept 1980. Pretoria, South Africa: Department of Statistics.

Somerville EW. Perthes' disease of the hip. J Bone Joint Surg [Br] 1971;53-B:639-49.

Trueta J. Perthes' disease (Letters). Lancet 1960;i:383, 772.

Wynne-Davies R, Gormley J. The aetiology of Perthes' disease. J Bone Joint Surg [Br] 1978;60-B: 6-14. 